\title{
Dextrorotatory Chromomycins from the Marine Streptomyces sp. Associated to Palythoa caribaeorum
}

\author{
Francisco C. L. Pinto, ${ }^{\circledR a}$ Edilberto R. Silveira, ${ }^{\circledR a}$ Ana Caroline L. Vasconcelos, ${ }^{b}$ \\ Katharine G. D. Florêncio, ${ }^{b}$ Francisca A. S. Oliveira, ${ }^{b}$ Bianca B. Sahm, ${ }^{c}$ \\ Letícia V. Costa-Lotufo, ${ }^{\circ c}$ Anelize Bauermeister, ${ }^{c, d}$ Norberto P. Lopes, ${ }^{d}$ \\ Diego V. Wilke ${ }^{\circledR, b}$ and Otília D. L. Pessoa ${ }^{\circledR *, a}$ \\ a Departamento de Química Orgânica e Inorgânica, Universidade Federal do Ceará, \\ 60021-970 Fortaleza-CE, Brazil \\ ${ }^{b}$ Núcleo de Pesquisa e Desenvolvimento de Medicamentos, Departamento de Fisiologia e Farmacologia, \\ Universidade Federal do Ceará, 60430-275 Fortaleza-CE, Brazil \\ 'Departamento de Farmacologia, Instituto de Ciências Biomédicas, Universidade de São Paulo, \\ 05508-900 São Paulo-SP, Brazil \\ ${ }^{d}$ Departamento de Física e Química, Faculdade de Ciências Farmacêuticas de Ribeirão Preto, \\ Universidade de São Paulo, 14040-903 Ribeirão Preto-SP, Brazil
}

\begin{abstract}
A Streptomyces sp. (BRA-384) was selected among nine strains of bacteria isolated from the zoanthids Palythoa caribaeorum due to the high cytotoxic activity presented by its EtOAc extract (inhibitory concentration mean $\left(\mathrm{IC}_{50}\right)$ of $2 \mathrm{ng} \mathrm{mL}-1$ ) against colon cancer cell line. From the EtOAc extract of BRA-384 three new chemical entities $\left(\mathrm{A}_{6}, \mathrm{~A}_{7}\right.$ and $\left.\mathrm{A}_{8}\right)$ and one dextrorotatory chromomycin $\left(\mathrm{A}_{5}\right)$, a promising class of anticancer compounds, were identified. The cytotoxicity of chromomycins $\mathrm{A}_{5}$ to $\mathrm{A}_{8}$ was tested against five tumor cell lines (HCT 116 (human colon adenocarcinoma), MCF-7 (human breast carcinoma), PC-3M (human metastatic prostate cancer), 501-mel (human metastatic melanoma) and MM200 (metastatic melanoma)). All chromomycins were highly potent showing $\mathrm{IC}_{50}$ values from 0.2 to $133 \mathrm{nM}$. Chromomycin $\mathrm{A}_{5}$ was consistently the most potent over all tested cells ( $\mathrm{IC}_{50}$ values from 0.2 in MM200 to $7.9 \mathrm{nM}$ in PC-3M), inclusive when compared to the standard chemotherapeutic agent doxorubicin, that presented $\mathrm{IC}_{50}$ values ranging from 147 to $568 \mathrm{nM}$ against MM200 and MCF-7, respectively.
\end{abstract}

Keywords: Palythoa caribaeorum, chromomycins, cytotoxic activity

\section{Introduction}

Marine microorganisms have emerged as an immensurable resource of bioactive compounds. Among the microbial sources, the actinomycetes, filamentous Gram-positive bacteria, have been highlighted as producers of a great number of active secondary metabolites. In fact, there is evidence that ca. 10,000 active compounds have been discovered from actinomycetes, representing $43 \%$ of all bioactive microbial metabolites. ${ }^{1,2}$ Among the actinomycetes, the genus Streptomyces (family: Streptomycetaceae, order: Actinomycetales) has been considered as the major producer of active compounds,

*e-mail: diegowilke@gmail.com; otilialoiola@gmail.com contributing significantly to cancer treatments. ${ }^{3,4}$ Several antitumor compounds currently used in human chemotherapy are produced by Streptomyces species, and includes the actinomycin, mitomycin, anthracycline, bleomycin, pentostatin, resistomycin and aureolic acid families. ${ }^{1,5}$

Chromomycins are tricyclic glycosylated polyketides, produced by terrestrial and marine bacteria of the genus Streptomyces belonging to the aureolic acid family., ${ }^{4,-8}$ Initially, the interest in chromomycins was due to their antimicrobial properties, ${ }^{9}$ but, nowadays, the main goal of studying chromomycins is related to their anticancer activity and antiproliferative properties., ${ }^{4,10,11}$ These molecules bind to the deoxyribonucleic acid (DNA) minor grove, causing DNA damage of treated cells, enhancing the expression 
of apoptosis related genes. ${ }^{12,13}$ Most of this knowledge is related to chromomycin $\mathrm{A}_{3}$ effects, but it is assumed to be true for the whole family of compounds. Previously, we reported ${ }^{14}$ autophagy induction on melanoma cells by chromomycin $\mathrm{A}_{2}$ isolated from Streptomyces sp. recovered from marine sediment.

As part of a program on marine natural products bioprospection, we have devoted our attention to the study of the zoanthids Palythoa caribaeorum and Palythoa variabilis, two abundant zoanthids in the Brazilian coast. ${ }^{15}$ Recently, we have extended the scope of our research investigating the chemical and microbiological profiles of these species from the Brazilian coast through an omics approach which revealed a great chemical and biosynthetic gene clusters diversity. ${ }^{15}$ In this paper, we present the isolation and structure elucidation of four dextrorotatory chromomycins from a cytotoxic extract produced by a Streptomyces bacteria strain recovered from the zoanthid P. caribaeorum, collected at Pedra Rachada Beach, located on the west coast of Ceará State, including the previously described chromomycin $\mathrm{A}_{5} \cdot{ }^{10}$ The cytotoxic activity of the isolated compounds was evaluated in a panel of five tumor cell lines, including melanoma, breast, colon and prostate carcinomas.

\section{Results and Discussion}

A total of nine bacterial strains were isolated from the zoanthids $P$. caribaeorum and $P$. variabilis collected at Taíba and Pedra Rachada beaches (Ceará State) in the northeastern Brazil coast. The bacteria were cultured, and their crude EtOAc extracts were evaluated against the human HCT 116 colon cancer cells. The most active extract, from the BRA-384 strain, showed an inhibitory concentration mean $\left(\mathrm{IC}_{50}\right)$ value equal to $2 \mathrm{ng} \mathrm{mL}^{-1}$, and therefore, it was selected to be further investigated. BRA-384 was identified as Streptomyces sp. based on the $16 \mathrm{~S}$ rRNA sequencing by comparison to the sequences present at $\mathrm{NCBI}^{16}$ using basic local alignment search tool (BLAST) followed by phylogenetic analysis (Figure S1, Supplementary Information (SI) section).

In this study, the time-course of the production of chromomycins (1 to $\mathbf{4}$ ) by BRA-384 was investigated (Figure 1a). Firstly, the chromatographic conditions to the identification of each peak of the chromomycins were established (see Figure S2, SI section). Once the aureolic acid is the common chromophore of all these molecules, ${ }^{4}$ a positive correlation of the peak areas with the quantity of chromomycin was expected. The peaks of compound $\mathbf{1}$ increased, while $\mathbf{3}$ diminished progressively from $1 \mathrm{~h}$ to 9 days. On the other hand, compound 2 depicted larger peaks at days 5 and 7. Compound $\mathbf{4}$ detection was always much lower than compounds 1-3. Additionally, when the BRA-384 strain was removed from the culture broth, by filtration $(0.22 \mu \mathrm{m})$, the extracts kept the same profile until day 9 (see Figure S3, SI section). These data suggested that the variation in the relative amounts of chromomycins were made by the bacteria itself, once all the culture conditions were the same, except by the bacteria removal. The biomass and organic extract yielding increased markedly on A1 culture broth with BRA-384 until day 7. The growth inhibition of HCT 116 cells was sustained above $80 \%$ by all the organic extracts tested at $50 \mu \mathrm{g} \mathrm{mL} \mathrm{m}^{-1}$ (data not shown). Once the cytotoxicity potency of chromomycins is well known, this high growth inhibition was expected. Based on these observations, we performed BRA-384 extractions at day 6 aiming to achieve both favorable yield and optimized amounts of chromomycins as well.

Liquid chromatography (LC) analysis of the crude extract exhibited an UV profile $\left(\lambda_{\max } 410,320,280\right.$ and $235 \mathrm{~nm}$ ), which is characteristic of members of the aureolic acid family. ${ }^{410}$ The compounds associated with main peaks observed in the high-pressure liquid chromatography (HPLC) were isolated and the chemical structures were characterized by high resolution mass spectra (HRMS), and nuclear magnetic resonance (NMR). A preliminary analysis by ${ }^{1} \mathrm{H}$ NMR spectra (see Table 1 ) of the isolated compounds from the BRA-384 exhibited signals for two benzene protons $\left(\delta_{\mathrm{H}} 6.63-6.77\right)$, five anomeric protons $\left(\delta_{\mathrm{H}} 4.61-5.23\right)$, two methoxyls $\left(\delta_{\mathrm{H}} 3.51-3.61\right)$, seven methyl groups $\left(\delta_{\mathrm{H}} 1.18-2.19\right)$, and $O$-acylated groups $\left(\delta_{\mathrm{H}} 2.15-2.19\right)$, again typical of the aureolic acid family (chromomycin, mithramycin, olivomycin and durhamycin) ${ }^{6,8}$ Those compounds are structurally characterized by a tetrahydro antracenone substituted at C-3 and C-7 by aliphatic chains, and at C-2 and $\mathrm{C}-6$ by oligosaccharide chains constituted by oliose (sugars $\mathrm{A}$ and $\mathrm{B}$ ), olivose (sugars $\mathrm{C}$ and $\mathrm{D}$ ) and chromose (sugar E), which can be acetylated and/or $O$-methylated. ${ }^{6,89}$ Despite the common structural aspects, each member has a peculiar characteristic which enables its identification even in mixtures, for instance: while the chromomycins and mithramycins display a characteristic methyl at C-7, the durhamycins have a sec-butyl at the same position. On the other hand, olivomycins in turn, are not substituted in this position. .7, $, 10,17$ Although both chromomycins and mithramycins present the same aglycones, they differ in the stereochemistry of the sugar units. In chromomycins, the disaccharide at $\mathrm{C}-2$ is $\beta-\mathrm{A}(3 \rightarrow 1)-\alpha-\mathrm{B}$ and the trisaccharide at $\mathrm{C}-6$ is $\beta-\mathrm{C}(3 \rightarrow 1)-\beta-\mathrm{D}-(3 \rightarrow 1)-\alpha-\mathrm{E}$, whereas in mithramycins, all units glycosides have $\beta$-configuration at the anomeric carbons. ${ }^{10}$ These main differences are easily observed by NMR data. 
Compound 1, a yellow amorphous powder, had its molecular formula $\mathrm{C}_{57} \mathrm{H}_{82} \mathrm{O}_{26}$ determined by high resolution electrospray ionization mass spectrometry

(a)

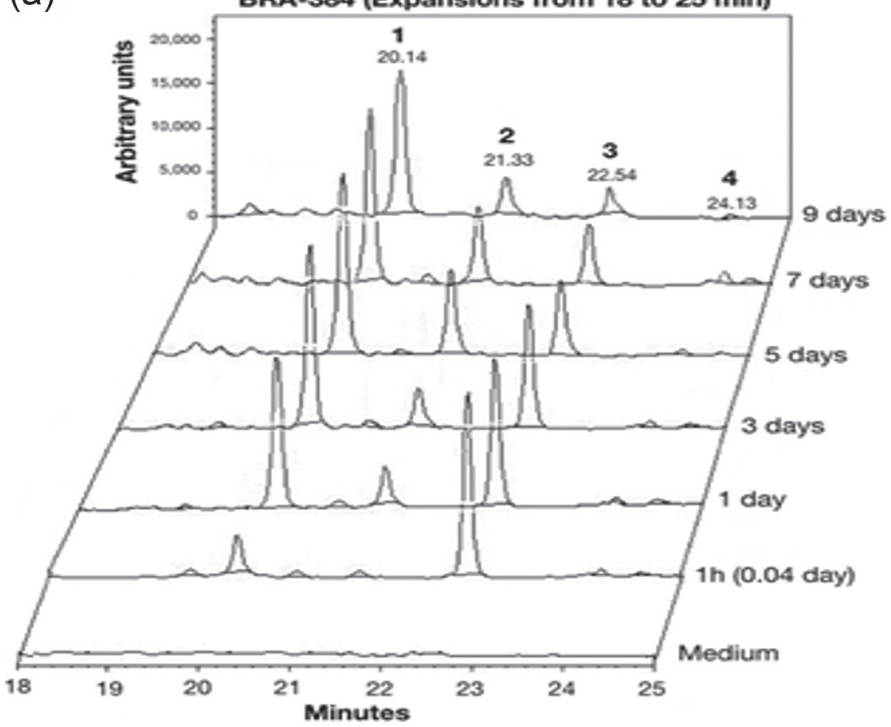

(HRESIMS) from the deprotonated molecular ion $[\mathrm{M}-\mathrm{H}]^{-}$ at $\mathrm{m} / \mathrm{z} 1181.4999$ (calcd. 1181.5022; 1.9 ppm error). Its ${ }^{1} \mathrm{H}$ NMR spectrum (see Table 1) displayed two chelated

(b)
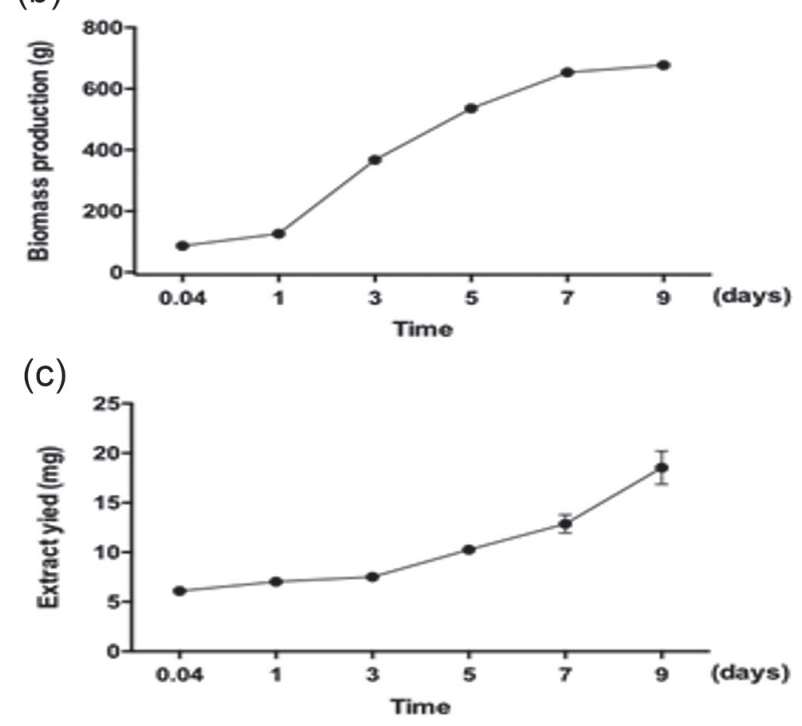

Figure 1. (a) Representative chromatograms expansion of the EtOAc extracts highlighting the chromomycins $\mathbf{1}$ to $\mathbf{4}$ production by Streptomyces sp. (BRA-384 strain) cultured in A1 broth monitored up to 9 days; (b) biomass production; (c) EtOAc extract yield of A1 broth of BRA-384 strain. The data are depicted as mean and standard deviation of experiments performed in triplicate.

Table 1. ${ }^{1} \mathrm{H}(500 \mathrm{MHz})$ and ${ }^{13} \mathrm{C}(75 \mathrm{MHz})$ NMR data assignments for 1-4 in $\mathrm{CDCl}_{3}$

\begin{tabular}{|c|c|c|c|c|c|c|c|}
\hline \multirow{2}{*}{ Position } & \multicolumn{2}{|r|}{1} & \multicolumn{2}{|r|}{2} & \multicolumn{2}{|r|}{3} & \multirow{2}{*}{$\begin{array}{c}\mathbf{4} \\
\delta_{\mathrm{H}}(J \text { in } \mathrm{Hz})\end{array}$} \\
\hline & $\delta_{\mathrm{C}}$ & $\delta_{\mathrm{H}}(J$ in $\mathrm{Hz})$ & $\delta_{\mathrm{C}}$ & $\delta_{\mathrm{H}}(J$ in $\mathrm{Hz})$ & $\delta_{C}{ }^{a}$ & $\delta_{\mathrm{H}}(J$ in $\mathrm{Hz})$ & \\
\hline \multicolumn{8}{|c|}{ Aglycon moiety } \\
\hline 1 & 202.3 & & 202.0 & & 202.3 & & \\
\hline 2 & 76.2 & $4.73, \mathrm{~d}(12.0)$ & 75.9 & $4.73, \mathrm{~d}(11.5)$ & 76.1 & $4.73, \mathrm{~d}(11.2)$ & $4.73, \mathrm{~d}(11.4)$ \\
\hline 3 & 43.9 & $2.58, \mathrm{~m}$ & 43.7 & $2.58, \mathrm{~m}$ & 43.8 & $2.58, \mathrm{~m}$ & $2.58, \mathrm{~m}$ \\
\hline \multirow[t]{2}{*}{4} & 27.1 & $3.10, \mathrm{~d}(12.8)$ & 27.3 & $3.10, \mathrm{~d}(12.3)$ & 27.1 & $3.10, \mathrm{~d}(12.3)$ & $3.10, \mathrm{~d}(12.8)$ \\
\hline & & $2.69, \mathrm{~m}$ & & $2.69, \mathrm{~m}$ & & $2.69, \mathrm{~m}$ & $2.69, \mathrm{~m}$ \\
\hline 5 & 101.1 & $6.65, \mathrm{~s}$ & 100.9 & $6.67, \mathrm{~s}$ & 100.9 & $6.63, \mathrm{~s}$ & $6.65, \mathrm{~s}$ \\
\hline 6 & 159.9 & & 159.5 & & 159.8 & & \\
\hline 7 & 111.9 & & 111.7 & & 111.8 & & \\
\hline 8 & 156.4 & & 156.3 & & 156.2 & & \\
\hline 9 & 165.5 & & 165.5 & & 165.4 & & \\
\hline 10 & 117.2 & $6.76, \mathrm{~s}$ & 116.8 & $6.77, \mathrm{~s}$ & 117.2 & $6.75, \mathrm{~s}$ & $6.75, \mathrm{~s}$ \\
\hline $4 \mathrm{a}$ & 134.8 & & 134.4 & & 134.7 & & \\
\hline $8 a$ & 108.3 & & 108.1 & & 108.2 & & \\
\hline $9 \mathrm{a}$ & 108.3 & & 108.4 & & 108.2 & & \\
\hline $10 \mathrm{a}$ & 138.6 & & 138.9 & & 138.5 & & \\
\hline 7-Me & 8.4 & $2.19, \mathrm{~s}$ & 8.5 & $2.19, \mathrm{~s}$ & 8.4 & $2.18, \mathrm{~s}$ & $2.18, \mathrm{~s}$ \\
\hline $8-\mathrm{OH}$ & & $9.83, \mathrm{~s}$ & & $9.83, \mathrm{~s}$ & & $9.82, \mathrm{~s}$ & $9.83, \mathrm{~s}$ \\
\hline 9-OH & & $15.71, \mathrm{~s}$ & & $15.71, \mathrm{~s}$ & & $15.71, \mathrm{~s}$ & $15.71, \mathrm{~s}$ \\
\hline 1 , & 82.0 & $4.72, \mathrm{~d}(1.5)$ & 81.8 & $4.72, \mathrm{~d}(1.5)$ & 82.1 & $4.72, \mathrm{~d}(1.5)$ & $4.70, \mathrm{~d}(1.4)$ \\
\hline 2 ' & 211.5 & & 211.3 & & 211.5 & & \\
\hline 3 ' & 78.4 & 4.23 , br s & 78.2 & $4.23, \mathrm{br} \mathrm{s}$ & 78.4 & 4.23 , br s & 4.21 , br s \\
\hline 4, & 68.1 & 4.37, br q (6.7) & 67.9 & 4.37, br q $(6.5)$ & 68.0 & 4.37, br q (6.4) & 4.37, br q (6.7) \\
\hline 5, & 20.8 & $1.37, \mathrm{~d}(6.7)$ & 20.9 & $1.37, \mathrm{~d}(6.5)$ & 20.6 & $1.37, \mathrm{~d}(6.4)$ & $1.37, \mathrm{~d}(6.7)$ \\
\hline 1'-OMe & 59.9 & $3.53, \mathrm{~s}$ & 59.6 & $3.53, \mathrm{~s}$ & 59.8 & $3.53, \mathrm{~s}$ & $3.51, \mathrm{~s}$ \\
\hline
\end{tabular}


Table 1. ${ }^{1} \mathrm{H}(500 \mathrm{MHz})$ and ${ }^{13} \mathrm{C}(75 \mathrm{MHz}) \mathrm{NMR}$ data assignments for $\mathbf{1 - 4}$ in $\mathrm{CDCl}_{3}$ (cont.)

\begin{tabular}{|c|c|c|c|c|c|c|c|}
\hline \multirow{2}{*}{ Position } & \multicolumn{2}{|r|}{1} & \multicolumn{2}{|r|}{2} & \multicolumn{2}{|r|}{3} & \multirow{2}{*}{$\begin{array}{c}\mathbf{4} \\
\delta_{\mathrm{H}}(J \text { in } \mathrm{Hz}) \\
\end{array}$} \\
\hline & $\delta_{\mathrm{C}}$ & $\delta_{\mathrm{H}}(\mathrm{J}$ in $\mathrm{Hz})$ & $\delta_{\mathrm{C}}$ & $\delta_{\mathrm{H}}(\mathrm{J}$ in $\mathrm{Hz})$ & $\delta_{\mathrm{C}}{ }^{\mathrm{a}}$ & $\delta_{\mathrm{H}}(J$ in $\mathrm{Hz})$ & \\
\hline \multicolumn{8}{|l|}{ Sugar A } \\
\hline $\mathrm{A} 1$ & 97.6 & $5.22, \mathrm{dd}(10.8,2.9)$ & 97.4 & $5.23, \mathrm{dd}(9.9,2.0)$ & 97.6 & $5.22, \mathrm{dd}(9.9,2.4)$ & $5.23, \mathrm{dd}(9.9,2.4)$ \\
\hline \multirow[t]{2}{*}{ A2 } & 33.1 & $2.21, \mathrm{~m}$ & 32.9 & $2.21, \mathrm{~m}$ & 33.2 & $2.21, \mathrm{~m}$ & $2.21, \mathrm{~m}$ \\
\hline & & $2.06, \mathrm{~m}$ & & $2.07, \mathrm{~m}$ & & $2.06, \mathrm{~m}$ & $2.06, \mathrm{~m}$ \\
\hline A3 & 70.2 & $4.00, \mathrm{~m}$ & 69.9 & $4.00, \mathrm{~m}$ & 70.0 & $4.00, \mathrm{~m}$ & $3.99, \mathrm{~m}$ \\
\hline A4 & 67.5 & $5.18, \mathrm{~d}(2.6)$ & 67.0 & $5.18, \mathrm{~d}(2.8)$ & 67.4 & $5.18, \mathrm{~d}(2.4)$ & $5.18, \mathrm{~d}(2.1)$ \\
\hline A5 & 69.9 & 3.83 , br q $(6.5)$ & 69.7 & 3.83 , br q $(6.5)$ & 69.9 & 3.82 , br q (6.2) & 3.81, br q $(6.2)$ \\
\hline A6 & 17.0 & $1.29, \mathrm{~d}(6.5)$ & 16.9 & $1.29, \mathrm{~d}(6.5)$ & 16.9 & $1.29, \mathrm{~d}(6.2)$ & $1.29, \mathrm{~d}(6.2)$ \\
\hline A4-O- & acetyl & & acetyl & & acetyl & & propionyl \\
\hline $1 "$ & 171.1 & & 170.8 & & 171.1 & & \\
\hline $2 "$ & 21.0 & $2.18, \mathrm{~s}$ & 20.9 & $2.18, \mathrm{~s}$ & 21.0 & $2.19, \mathrm{~s}$ & $2.45, \mathrm{q}(7.1)$ \\
\hline 3" & & & & & & & $1.20, \mathrm{t}(7.1)$ \\
\hline \multicolumn{8}{|l|}{ Sugar B } \\
\hline B1 & 95.4 & 5.13 , br s & 95.1 & 5.12 , br s & 95.3 & 5.13 , br s & 5.11 , br s \\
\hline \multirow[t]{2}{*}{ B2 } & 33.7 & $1.77, \mathrm{~m}$ & 33.5 & $1.77, \mathrm{~m}$ & 33.6 & $1.77, \mathrm{~m}$ & $1.77, \mathrm{~m}$ \\
\hline & & $1.75, \mathrm{~m}$ & & $1.75, \mathrm{~m}$ & & $1.75, \mathrm{~m}$ & $1.75, \mathrm{~m}$ \\
\hline B3 & 66.1 & $4.00, \mathrm{~m}$ & 66.3 & $4.00, \mathrm{~m}$ & 66.0 & $4.00, \mathrm{~m}$ & $3.99, \mathrm{~m}$ \\
\hline B4 & 81.7 & $3.23, \mathrm{~d}(2.6)$ & 81.5 & $3.23, \mathrm{~d}(3.0)$ & 81.7 & $3.23, \mathrm{~d}(2.7)$ & $3.23, \mathrm{~d}(1.8)$ \\
\hline B5 & 66.9 & 3.88, br q $(6.5)$ & 66.9 & 3.88, br q $(6.8)$ & 66.8 & 3.88, br q $(6.5)$ & 3.88, br q $(6.7)$ \\
\hline B6 & 17.5 & $1.30, \mathrm{~d}(6.5)$ & 17.2 & $1.30, \mathrm{~d}(6.8)$ & 17.4 & $1.30, \mathrm{~d}(6.5)$ & $1.30, \mathrm{~d}(6.7)$ \\
\hline B4-OMe & 62.6 & $3.61, \mathrm{~s}$ & 62.3 & $3.61, \mathrm{~s}$ & 62.5 & $3.61, \mathrm{~s}$ & $3.59, \mathrm{~s}$ \\
\hline \multicolumn{8}{|l|}{ Sugar C } \\
\hline $\mathrm{C} 1$ & 100.5 & $5.10, \mathrm{dd}(9.0,2.0)$ & 100.2 & $5.10, \mathrm{dd}(9.8,1.8)$ & 100.5 & $5.10, \mathrm{dd}(9.8,2.1)$ & $5.08, \mathrm{dd}(9.7,2.1)$ \\
\hline \multirow[t]{2}{*}{$\mathrm{C} 2$} & 37.7 & $2.50, \mathrm{~m}$ & 37.6 & $2.50, \mathrm{~m}$ & 37.6 & $2.50, \mathrm{~m}$ & $2.49, \mathrm{~m}$ \\
\hline & & $1.72, \mathrm{~m}$ & & $1.72, \mathrm{~m}$ & & $1.72, \mathrm{~m}$ & $1.72, \mathrm{~m}$ \\
\hline $\mathrm{C} 3$ & 82.5 & $3.59, \mathrm{~m}$ & 82.2 & $3.59, \mathrm{~m}$ & 82.5 & $3.59, \mathrm{~m}$ & $3.59, \mathrm{~m}$ \\
\hline $\mathrm{C} 4$ & 75.3 & $3.14, \mathrm{~d}(8.0)$ & 75.2 & $3.14, \mathrm{~d}(8.6)$ & 75.3 & $3.14, \mathrm{~d}(7.7)$ & $3.12, \mathrm{~d}(8.9)$ \\
\hline C5 & 72.4 & $3.32, \mathrm{dq}(8.0,6.9)$ & 72.3 & $3.32, \mathrm{dq}(8.6,6.9)$ & 72.3 & $3.32, \mathrm{dq}(7.7,6.9)$ & $3.32, \mathrm{dq}(8.9,6.0)$ \\
\hline C6 & 18.2 & $1.38, \mathrm{~d}(6.9)$ & 18.1 & $1.38, \mathrm{~d}(6.9)$ & 18.2 & $1.38, \mathrm{~d}(6.9)$ & $1.38, \mathrm{~d}(6.0)$ \\
\hline \multicolumn{8}{|l|}{ Sugar D } \\
\hline D1 & 99.9 & $4.63, \mathrm{~d}(9.5)$ & 99.7 & $4.63, \mathrm{~d}(9.6)$ & 99.9 & $4.61, \mathrm{~d}(9.5)$ & 4.61, d (9.4) \\
\hline \multirow[t]{2}{*}{ D2 } & 37.3 & $2.28, \mathrm{dd}(12.9,3.3)$ & 37.2 & $2.28, \mathrm{dd}(12.9,5.5)$ & 37.2 & $2.28, \mathrm{dd}(12.1,4.0)$ & $2.28, \mathrm{dd}(12.5,6.5)$ \\
\hline & & $1.68, \mathrm{~m}$ & & $1.68, \mathrm{~m}$ & & $1.68, \mathrm{~m}$ & $1.68, \mathrm{~m}$ \\
\hline D3 & 80.9 & $3.50, \mathrm{~m}$ & 80.7 & $3.50, \mathrm{~m}$ & 80.7 & $3.50, \mathrm{~m}$ & $3.49, \mathrm{~m}$ \\
\hline D4 & 75.5 & $3.14, \mathrm{~d}(8.0)$ & 75.2 & $3.14, \mathrm{~d}(8.6)$ & 75.4 & $3.12, \mathrm{~d}(8.5)$ & $3.11, \mathrm{~d}(8.1)$ \\
\hline D5 & 72.5 & $3.39, \mathrm{dq}(8.0,6.8)$ & 72.2 & $3.40, \mathrm{dq}(8.6,6.8)$ & 72.4 & $3.40, \mathrm{dq}(8.5,6.0)$ & $3.39, \mathrm{dq}(8.1,6.0)$ \\
\hline D6 & 18.0 & $1.39, \mathrm{~d}(6.8)$ & 17.9 & $1.39, \mathrm{~d}(6.8)$ & 18.0 & $1.39, \mathrm{~d}(6.0)$ & $1.39, \mathrm{~d}(6.0)$ \\
\hline \multicolumn{8}{|l|}{ Sugar E } \\
\hline E1 & 97.3 & $5.03, \mathrm{dd}(4.5,1.8)$ & 97.1 & $5.03, \mathrm{dd}(4.3,2.0)$ & 97.2 & $5.03, \mathrm{dd}(4.8,2.4)$ & $5.01, \mathrm{dd}(3.5,1.7)$ \\
\hline \multirow[t]{2}{*}{ E2 } & 43.9 & $2.06, \mathrm{~m}$ & 43.9 & $2.07, \mathrm{~m}$ & 43.9 & $2.07, \mathrm{~m}$ & $2.05, \mathrm{~m}$ \\
\hline & & $2.00, \mathrm{~m}$ & & $2.02, \mathrm{~m}$ & & $2.00, \mathrm{~m}$ & $2.00, \mathrm{~m}$ \\
\hline E3 & 70.8 & & 70.5 & & 70.8 & & \\
\hline E4 & 79.8 & $4.61, \mathrm{~d}(9.0)$ & 79.6 & $4.61, \mathrm{~d}(9.0)$ & 79.5 & $4.61, \mathrm{~d}(9.5)$ & $4.61, \mathrm{~d}(9.4)$ \\
\hline E5 & 67.2 & $4.00, \mathrm{~m}$ & 67.0 & $4.00, \mathrm{~m}$ & 67.2 & $4.00, \mathrm{~m}$ & $3.99, \mathrm{~m}$ \\
\hline E6 & 18.0 & $1.24, \mathrm{~d}(6.3)$ & 18.0 & $1.24, \mathrm{~d}(6.5)$ & 18.0 & $1.24, \mathrm{~d}(6.5)$ & $1.24, \mathrm{~d}(6.5)$ \\
\hline E3-Me & 23.2 & $1.37, \mathrm{~s}$ & 23.2 & $1.36, \mathrm{~s}$ & 23.1 & $1.36, \mathrm{~s}$ & $1.36, \mathrm{~s}$ \\
\hline E4-O- & acetyl & & propionyl & & isobutyryl & & isobutyryl \\
\hline $1 " ”$ & 171.5 & & 175.3 & & 177.7 & & \\
\hline 2"' & 21.0 & $2.15, \mathrm{~s}$ & 27.8 & $2.44, q(7.5)$ & 34.4 & $2.65, \mathrm{~m}$ & $2.62, \mathrm{~m}$ \\
\hline $3 " ”$ & & & 9.3 & $1.19, \mathrm{t}(7.5)$ & 19.1 & $1.21, \mathrm{~d}(7.0)$ & $1.18, \mathrm{t}(7.1)$ \\
\hline 4"” & & & & & 19.1 & $1.21, \mathrm{~d}(7.0)$ & $1.18, \mathrm{t}(7.1)$ \\
\hline
\end{tabular}

${ }^{\text {a Signals }}{ }^{13} \mathrm{C}$ NMR for the down-field were obtained by ${ }^{1} \mathrm{H} \times{ }^{13} \mathrm{C}$ correlations of HSQC and HMBC. 
phenol protons at $\delta_{\mathrm{H}} 15.71(9-\mathrm{OH})$ and $9.83(8-\mathrm{OH})$, two singlets for benzene protons at $\delta_{\mathrm{H}} 6.76(\mathrm{H}-10)$ and 6.65 $(\mathrm{H}-5)$, five anomeric protons at $\delta_{\mathrm{H}} 5.22(\mathrm{~d}, J 10.8,2.9 \mathrm{~Hz}$, A1), 5.13 (br s, B1), 5.10 (d, J 9.0, $2.0 \mathrm{~Hz}, \mathrm{C} 1), 5.03$ $(\mathrm{dd}, J 4.5,1.8 \mathrm{~Hz}, \mathrm{E} 1)$ and $4.63(\mathrm{~d}, J 9.5 \mathrm{~Hz}, \mathrm{D} 1)$, and two methoxyl groups at $\delta_{\mathrm{H}} 3.61$ (s, MeO-B4) and 3.58 (s, MeO-1'). In addition, the ${ }^{1} \mathrm{H}$ NMR spectrum showed signals to twelve methyl groups, including those at $\delta_{\mathrm{H}} 2.19$ (s, Me-7), 2.18 (MeCO-A4) and 2.15 (MeCO-E4). The ${ }^{13} \mathrm{C}$ NMR and heteronuclear single quantum correlation (HSQC) spectra displayed signals to 57 carbon atoms (see Table 1), assignable to the twelve methyl groups as observed in the ${ }^{1} \mathrm{H}$ NMR spectrum including those corresponding to two methoxyls and two acetyl groups, six methylenes, and twenty-four methines, including the anomeric carbons. Comparatively, 13 non-hydrogenated carbons, including two ketone carbonyls $\left[\delta_{\mathrm{C}} 211.5\left(\mathrm{C}-2^{\prime}\right)\right.$ and $202.3(\mathrm{C}-1)]$ and two acetyl carboxyls $\left[\delta_{\mathrm{C}} 171.5\right.$ (MeCO-E4) and 171.1 (MeCO-A4)] what is in accordance with the ${ }^{1} \mathrm{H}$ NMR spectrum that showed two methyls of acetyl esters. Comparison of the ${ }^{1} \mathrm{H}$ and ${ }^{13} \mathrm{C}$ NMR data of $\mathbf{1}$ with those previously reported to chromomycin $\mathrm{A}_{3}$ $[\alpha]_{\mathrm{D}}^{20}-42.0^{\circ}$ (c 1.0, EtOH) indicated remarkable similarities, ${ }^{18}$ since no significant differences in the chemical shifts (larger difference $\Delta \delta_{\mathrm{C}} 0.4 \mathrm{ppm}$ and $\Delta \delta_{\mathrm{H}} 0.09 \mathrm{ppm}$ ) were observed (see Table $\mathrm{S} 1$, SI section). Nevertheless, the dextrorotatory specific rotation of $[\alpha]_{\mathrm{D}}^{20}+48.2^{\circ}(c 0.1, \mathrm{MeOH})$ observed for $\mathbf{1}$, indicated that these compounds are, indeed, stereoisomers. The complete ${ }^{1} \mathrm{H}$ and ${ }^{13} \mathrm{C}$ NMR assignments of $\mathbf{1}$ were made by a combination of ${ }^{1} \mathrm{H}$ and ${ }^{13} \mathrm{C}$ NMR, correlation spectroscopy (COSY), HSQC and heteronuclear multiple bond correlation (HMBC) experiments (see Figures S4-S10, SI section). Based on the above data $\mathbf{1}$ is a new member of aureolic acid family and following the denotation adopted for the five chromomycins already reported, it was assigned as chromomycin $\mathrm{A}_{6}$.

Compound $\mathbf{2}$ was also isolated as a yellow amorphous powder. Its molecular formula was established as $\mathrm{C}_{58} \mathrm{H}_{84} \mathrm{O}_{26}$ based on the $[\mathrm{M}-\mathrm{H}]^{-}$ion peak observed by HRESIMS for the deprotonated molecular ion at $\mathrm{m} / \mathrm{z}, 1195.5169$ (calcd. $1195.5178,0.8 \mathrm{ppm}$ error). A detailed analysis of the 1D and 2D NMR spectra revealed that $\mathbf{2}$ shared high structural similarity to 1 being the difference related to the presence of a propionyl moiety as established by the ${ }^{1} \mathrm{H}$ and ${ }^{13} \mathrm{C}$ NMR data $\left(\delta_{\mathrm{C}} / \delta_{\mathrm{H}} 175.3(\mathrm{C}=\mathrm{O}), 27.8 / 2.44\left(\mathrm{q}, J 7.9 \mathrm{~Hz}, \mathrm{CH}_{2}\right)\right.$ and 9.3/1.18 (t, $\left.J 7.9 \mathrm{~Hz}, \mathrm{CH}_{3}\right)$ ) instead an acetyl group (see Table 1). The unequivocal positioning of the propionyl moiety at C-E4 $\left(\delta_{\mathrm{C}} 79.6\right)$ was confirmed by the HMBC correlation of the proton signal at $\delta_{\mathrm{H}} 4.61(\mathrm{~d}, J 9.0 \mathrm{~Hz}$, $\mathrm{H}$-E4) with the ester carbonyl at $\delta_{\mathrm{C}} 175.3\left(\mathrm{CH}_{3} \mathrm{CH}_{2} \mathrm{CO}-\mathrm{E} 4\right)$,
70.5 (C-E3), 67.0 (C-E5) and 18.0 (C-E6). The above data support a structure similar to that of chromomycin $\mathrm{A}_{\mathrm{p}}$ (patent number 64967-61-9), ${ }^{19}$ which was previously isolated from a Streptomyces griseus strain. Although the authors of the patent have stated that they have used NMR data, we were not able to find them, making it impossible to do any comparative analysis. However, the optical rotation described of $[\alpha]_{\mathrm{D}}^{20}-56.0^{\circ}(c 0.1, \mathrm{EtOH})^{19}$ had the opposite sign to that found for $2[\alpha]_{D}^{20}+18.4^{\circ}(c 0.1, \mathrm{MeOH})$, suggesting that these compounds are indeed stereoisomers. However, the lack of NMR data for chromomycin $\mathrm{A}_{\mathrm{p}}$ does not permit to conclude whether they are diastereomers or enantiomers. Thus, compound $\mathbf{2}$ was assigned as the new chromomycin $\mathrm{A}_{7}$.

Compound 3, also isolated as a yellow amorphous powder, had its molecular formula described as $\mathrm{C}_{59} \mathrm{H}_{86} \mathrm{O}_{26}$ based on the deprotonated molecular $[\mathrm{M}-\mathrm{H}]^{-}$ion peak at $\mathrm{m} / \mathrm{z} 1209.5274$ (calcd. 1209.5308, $2.8 \mathrm{ppm}$ error) as observed in the HRESIMS. The ${ }^{1} \mathrm{H}$ and ${ }^{13} \mathrm{C}$ NMR spectra also showed typical signals for a chromomycin nucleus. From a detailed analysis of their 1D and 2D NMR data it was obvious that $\mathbf{3}$ had a structure similar to $\mathbf{1}$ and $\mathbf{2}$ only differing in the replacement of the acetyl (MeCO-A4) in $\mathbf{1}$ or the propionyl $\left(\mathrm{CH}_{3} \mathrm{CH}_{2} \mathrm{CO}-\mathrm{E} 4\right)$ in $\mathbf{2}$ by an isobutyryl moiety as evidenced by the chemical shifts at $\delta_{\mathrm{C}} / \delta_{\mathrm{H}} 177.7$ $(\mathrm{C}=\mathrm{O}), 34.4 / 2.65(\mathrm{~m}, \mathrm{CH}), 19.1 / 1.21\left(\mathrm{~d}, J 7.0 \mathrm{~Hz}, \mathrm{CH}_{3}\right)$ and 19.1/1.21 (d, $\left.J 7.0 \mathrm{~Hz}, \mathrm{CH}_{3}\right)$ in the ${ }^{1} \mathrm{H}$ and ${ }^{13} \mathrm{C}$ NMR spectra (see Table 1). The unequivocal position of the isobutyryl group at C-E4 $\left(\delta_{\mathrm{C}} 79.5\right)$ was confirmed by the HMBC correlation of the H-E4 at $\delta_{\mathrm{H}} 4.61(\mathrm{~d}, J 9.6 \mathrm{~Hz})$ with the ester carboxyl at $\delta_{\mathrm{C}} 177.7(\mathrm{C}=\mathrm{O})$. Analysis of ${ }^{1} \mathrm{H}$ and ${ }^{13} \mathrm{C}$ NMR data allowed to suggest an identical structure to those of chromomycin $\mathrm{A}_{5}[\alpha]_{\mathrm{D}}^{24}+57.6^{\circ}(c 0.035, \mathrm{EtOH})^{10}$ or chromomycin $\mathrm{A}_{2}[\alpha]_{\mathrm{D}}^{24}-61.4^{\circ}(c 1.0, \mathrm{EtOH})^{19}$ since the subtle differences in the NMR data are not enough to differentiate one from each other (see Tables S2 and S3, SI section). Nevertheless, the positive optical rotation $[\alpha]_{\mathrm{D}}^{20}+48.8^{\circ}(c 0.1, \mathrm{MeOH})$ observed for 3 , led to the conclusion that $\mathbf{3}$ was indeed chromomycin $\mathrm{A}_{5}$. This compound was firstly obtained from a microorganism identified as Streptomyces sp. recovered from sedimentary specimen collected on the Beaufort Sea coast of Alaska by Pettit et al., ${ }^{10}$ who described chromomycin $\mathrm{A}_{5}$ as a stereoisomer of chromomycin $\mathrm{A}_{2}$ at C-2 and/or C-3.

Compound 4, a yellow amorphous powder, also exhibited a dextrorotatory specific rotation $[\alpha]_{\mathrm{D}}^{20}+8.1^{\circ}$ (c $0.1, \mathrm{MeOH}$ ). Its molecular formula of $\mathrm{C}_{60} \mathrm{H}_{88} \mathrm{O}_{26}$ was determined by HRESIMS which exhibited a $[\mathrm{M}-\mathrm{H}]^{-}$ion peak at $\mathrm{m} / \mathrm{z} 1223.5455$ (calcd. 1223.5491, $2.9 \mathrm{ppm}$ error) indicating 14 a.m.u. higher than compound 3 . Its ${ }^{1} \mathrm{H}$ NMR data were similar to those of $\mathbf{3}$ (see Table 1 ) only differing by 
an extra methylene signal consistent with the replacement of the acetyl group in 3 by a propionyl moiety $\left[\delta_{\mathrm{H}} 2.44\right.$ (q, $J 7.1 \mathrm{~Hz})$ and $1.20(\mathrm{~d}, J 7.1 \mathrm{~Hz})]$ corroborating with the molecular formula. Although some chemical shifts were missing in the 2D NMR experiments, the signals related to the propionyl moiety were clearly observed in the HSQC spectrum $\left(\delta_{\mathrm{H}} 2.44 / \delta_{\mathrm{C}} 27.0\right.$ and $\left.1.20 / \delta_{\mathrm{C}} 9.0\right)$ as well as in the HMBC spectrum which displayed correlations for both the methylene $\left(\delta_{\mathrm{H}} 2.44\right)$ and the methyl $\left(\delta_{\mathrm{H}} 1.20\right)$ protons with the carboxyl ester at $\delta_{\mathrm{C}} 174.5(\mathrm{C}=\mathrm{O})$ supporting the suggested structure. Moreover, the mass fragmentation of $4\left\{\mathrm{~m} / z 917.38[\mathrm{M}+\mathrm{Na}]^{+}-\mathrm{G}_{\mathrm{AB}}\right.$ glycoside moiety (calcd. for $\mathrm{C}_{44} \mathrm{H}_{62} \mathrm{O}_{19} \mathrm{Na}$ ), $m / z, 773.27[\mathrm{M}+\mathrm{Na}]^{+}-\mathrm{G}_{\mathrm{CDE}}$ glycoside moiety (calcd. for $\mathrm{C}_{37} \mathrm{H}_{50} \mathrm{O}_{16} \mathrm{Na}$ ) and $\mathrm{m} / z 497.19$ $\left[\mathrm{G}_{\mathrm{CDE}}+\mathrm{Na}\right]^{+}-\mathrm{C}_{37} \mathrm{H}_{50} \mathrm{O}_{16}$ (calcd. for $\mathrm{C}_{23} \mathrm{H}_{38} \mathrm{O}_{10} \mathrm{Na}$ ) \} provided by LC-MS/MS gave additional argumentation to confirm the propionyl moiety at $\mathrm{C}-\mathrm{A} 4$ as shown in Figures 2 and S36 (SI section). Interestingly, Oki et al. ${ }^{20}$ isolated from a culture of Streptomyces sp. a chromomycin (codified as SR1768A) bearing a propionyl group at the same position. To the best of our knowledge, this was the only report on the isolation of this compound, but its NMR data and the optical rotation were not reported, which did not permit any comparison. Thus, we believe that chromomycin $\mathbf{4}$ is a new dextrorotatory entity of this family, and then, designated chromomycin $\mathrm{A}_{8}$.

Chromomycins, as well as other aureolic acids, are type II polyketides and their biosynthetic clusters include the genes for polyketide biosynthesis and modifications,

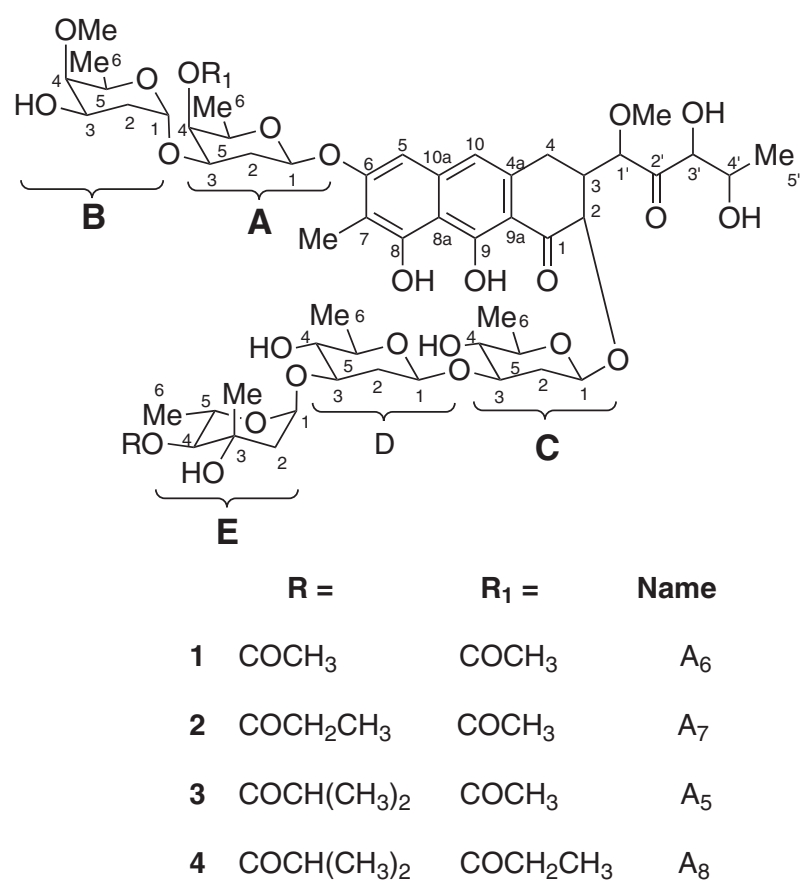

Figure 2. Molecular structures of chromomycins 1-4 isolated from Streptomyces sp. deoxysugar biosynthesis or sugar transfer, pathway regulation and resistance. ${ }^{6-8}$ Genome mining can be used to increase the production yield and also to obtain modified chromomycins. ${ }^{6-8}$ The compounds 1-4 share the same aglycone moiety showing only minor differences at C-A4 or C-E4 of the saccharide side chains (Figure 2). Concerning to the latter dissimilarities, the activity of CmmA acetyltransferase, an enzyme located in the cell membrane of Streptomyces which accepts several acylCoA substrates, could explain the acylation diversity of 1 to $4,{ }^{7}$ corroborating the data from time-course experiments, where the presence of the bacteria strain is responsible for the appearance of compounds 1-4 in the culture media.

The cytotoxicity of the compounds 1-4 was further evaluated against five human cell lines including the human tumor cell lines MCF-7 (breast carcinoma), HCT 116 (colon adenocarcinoma), PC-3M (metastatic prostate cancer), 501-mel (metastatic melanoma) and MM200 (metastatic melanoma). Chromomycins 1-4 were highly potent against tumor cells showing $\mathrm{IC}_{50}$ values ranging from $0.2 \mathrm{nM}$ for compound $\mathbf{3}$, over MM200 cells, to $133 \mathrm{nM}$ for compound $\mathbf{2}$ over MCF-7 cells. In fact, compound $\mathbf{3}$ was consistently more active throughout all tested cell lines. Doxorubicin, used as positive control, was far less active than compounds 1-4, being the biggest difference in the sensitivity of doxorubicin and chromomycin $\mathrm{A}_{5}(\mathbf{3})$ over HCT 116 cells, where the positive control was more than one thousand times less active (see Table 2).

Previous studies on the molecular interactions of chromomycin $\mathrm{A}_{3}$ and DNA revealed that this compound dimerizes, in a process coordinated by the presence of $\mathrm{Mg}^{2+}$, and binds to the minor groove of the DNA duplex. ${ }^{12}$ The binding involves the interaction of the chromophore and $\mathrm{D}, \mathrm{E}$ and $\mathrm{F}$ sugar moieties with residues of the minor grove, while A-B sugar moieties and part of the chromophore interact with the phosphate backbone. ${ }^{12}$ The C3-side chain is not directly related to the DNA binding properties, thus the influence in the observed cytotoxicity seemed to be secondary to modifications in the sugar moieties and the chromophore. A review in the literature regarding to chromomycins bearing the $\mathrm{CH}(\mathrm{OMe})-\mathrm{CO}-\mathrm{CH}(\mathrm{OH})-\mathrm{CH}(\mathrm{OH})-\mathrm{CH}_{3}$ side chain at $\mathrm{C}-3$ shows that only four chromomycins including the chromomycins $\mathrm{A}_{5},{ }^{10}$ DAC- $\mathrm{A}_{3},{ }^{4} 02-3 \mathrm{G}$ and $02-3 \mathrm{D},{ }^{21}$ exhibit positive optical rotation values. Indeed, Pettit et al. ${ }^{10}$ described chromomycin $\mathrm{A}_{5}$ as a potent cytotoxic compound as other aureolic acid analogues, showing $\mathrm{IC}_{50}$ values ranging from $0.73 \mathrm{ng} \mathrm{mL}^{-1}$ against MCF-7 to $4.3 \mathrm{ng} \mathrm{mL}^{-1}$ on colon cancer KM20L2 cells. The potency is quite similar to the one observed in the present work. 
Table 2. Cytotoxicity of chromomycins 1-4 on a panel of cell lines

\begin{tabular}{lccccc}
\hline \multirow{2}{*}{ Cell line } & \multicolumn{5}{c}{$\mathrm{IC}_{50}(95 \% \mathrm{CI}) / \mathrm{nM}$} \\
\cline { 2 - 6 } & $\mathbf{1}$ & $\mathbf{2}$ & $\mathbf{3}$ & $\mathbf{4}$ & Doxorubicin \\
\hline MCF-7 & $14.1(7.9-25.1)$ & $133.0(84-210.0)$ & $3.7(2.2-6.3)$ & $10.5(4.2-26.3)$ & $568.0(305-1058.0)$ \\
HCT 116 & $3.5(2.7-4.5)$ & $47.3(31.4-71.3)$ & $0.4(0.3-0.6)$ & $1.4(1.0-2.0)$ & $453.0(396.0-517.0)$ \\
501-mel & $2.3(1.7-2.7)$ & $49.0(31.3-76.7)$ & $0.8(0.5-1.0)$ & $1.6(1.1-2.2)$ & $400.0(384.0-563.0)$ \\
MM200 & $2.6(2.1-3.2)$ & $39.1(33.6-46.6)$ & $0.2(0.1-0.3)$ & $0.8(0.5-1.3)$ & $147.0(122.0-176.0)$ \\
PC-3M & $67.8(51.7-88.9)$ & n.t. & $7.9(6.5-9.5)$ & $88.3(70.8-110.1)$ & $799.2(426.3-1499.0)$ \\
\hline
\end{tabular}

MCF-7: human breast carcinoma; HCT 116: human colon adenocarcinoma; 501-mel: human metastatic melanoma; MM200: human melanoma; PC-3M: human metastatic prostate cancer. Activity was evaluated using the MTT assay after $72 \mathrm{~h}$ incubation. Doxorubicin was used as positive control. The inhibition concentration means $\left(\mathrm{IC}_{50}\right)$ and confidence interval of $95 \%$ (CI95\%) values were obtained by nonlinear regression of three independent experiments.

\section{Conclusions}

A Streptomyces sp. strain recovered from the zoanthid P. caribaeorum with presumable ability to biosynthesize only, or mainly, dextrorotatory chromomycins was investigated. The chromomycins $\mathrm{A}_{5}, \mathrm{~A}_{6}, \mathrm{~A}_{7}$ and $\mathrm{A}_{8}$ were highly cytotoxic, exhibiting an exciting profile of this class of compounds for antitumor application.

\section{Experimental}

\section{General}

Optical rotations were measured with a Jasco P-2000 polarimeter, operating with a tungsten lamp at a wavelength of $589 \mathrm{~nm}$ at $20^{\circ} \mathrm{C}$. HRESIMS spectra were acquired using a Shimadzu chromatographic system coupled to a mass spectrometer (Bruker Daltonics) equipped with an electrospray ionization source (ESI-) and a quadrupoletime-of-flight analyzer. 1D and $2 \mathrm{D}{ }^{1} \mathrm{H},{ }^{13} \mathrm{C}$ NMR spectra were obtained on a Bruker Avance DRX-500 or DPX-300 MHz spectrometers, using $\mathrm{CDCl}_{3}$ or $\mathrm{CD}_{3} \mathrm{OD}$ as solvent. A Shimadzu ultra-fast liquid chromatograph (UFLC) semi-preparative system (equipped with ternary pumps and diode array SPD-M20A UV-Vis detector) was used for high-performance liquid chromatography.

Sampling of zoanthids and isolation of their associated bacterial strains

\section{Colonies of Palythoa caribaeorum and Palythoa variabilis} (ca. $20 \mathrm{~g}$ of each colony) were sampled manually on the intertidal zone during the low tide at Pedra Rachada Beach,

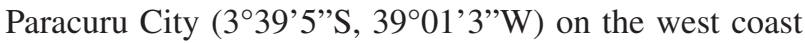
of Ceará State, of the northeastern Brazil. The specimens were sprayed with $70 \% \mathrm{EtOH} / \mathrm{H}_{2} \mathrm{O}(\mathrm{v} / \mathrm{v})$ for superficial decontamination, then washed with sterile seawater at the collection sites and kept in ice for $2 \mathrm{~h}$. The license for collection of zoanthids was granted by Biodiversity Authorization and Information System (SISBIO number 48522-2, SisGen number AC0781C). The samples were further processed under sterile conditions: extensively cut colonies of the zoanthids were spread on agar-media plates and incubated at room temperature (approximately $26^{\circ} \mathrm{C}$ ). From 2 to 6 weeks later, nine apparently different strains were separated from three different media: trace minerals agar (TMA) composed of $18 \mathrm{~g}$ agar, $1 \mathrm{~g}$ glucose, $1 \mathrm{~g}$ yeast extract, $7 \mathrm{~g} \mathrm{Na}_{2} \mathrm{HPO}_{4}, 1 \mathrm{~g} \mathrm{KNO}_{3}, 3 \mathrm{~g} \mathrm{NaCl}$, $1 \mathrm{~g} \mathrm{MgSO}_{4} \cdot 7 \mathrm{H}_{2} \mathrm{O}, 0.2 \mathrm{~g} \mathrm{CaCl}_{2} \cdot 2 \mathrm{H}_{2} \mathrm{O}, 0.2 \mathrm{~g} \mathrm{FeSO}_{4} \cdot 7 \mathrm{H}_{2} \mathrm{O}$, $0.18 \mathrm{~g} \mathrm{ZnSO}_{4} .7 \mathrm{H}_{2} \mathrm{O}, 0.02 \mathrm{~g} \mathrm{MnSO}_{4} \cdot 4 \mathrm{H}_{2} \mathrm{O}, 0.09 \mathrm{~g}$ $\mathrm{CuSO}_{4} .5 \mathrm{H}_{2} \mathrm{O}, 0.01 \mathrm{~g} \mathrm{CoSO}_{4} .7 \mathrm{H}_{2} \mathrm{O}, 0.1 \mathrm{~g} \mathrm{H}_{3} \mathrm{BO}_{3}$ and $0.1 \mathrm{~g}$ $\left(\mathrm{NH}_{4}\right) 6 \mathrm{Mo}_{7} \mathrm{O}_{24} \cdot 4 \mathrm{H}_{2} \mathrm{O}$ dissolved in $1 \mathrm{~L}$ of artificial seawater and supplemented with $0.1 \mathrm{mg} \mathrm{mL}^{-1}$ cycloheximide; sea water agar (SWA), composed of $18 \mathrm{~g}$ of agar dissolved in $1 \mathrm{~L}$ of artificial seawater; and starch casein agar (SCA), composed of $10 \mathrm{~g}$ of soluble starch, $1 \mathrm{~g}$ powdered casein, $15 \mathrm{~g}$ agar dissolved in $1 \mathrm{~L}$ of artificial seawater.

\section{Molecular identification of BRA-384 bacterial strain and} phylogenetic tree

A molecular based approach was carried out for taxonomic identification of the BRA-384 strain. The genomic DNA of the isolated was extracted as previously described ${ }^{22}$ with minor modifications. For DNA extraction the cell pellet from $1.0 \mathrm{~mL}$ of the BRA-384 culture was obtained and suspended in $500 \mu \mathrm{L}$ of cetyltrimethylammonium bromide (CTAB) lysis buffer for three cycles of freezing $\left(-70{ }^{\circ} \mathrm{C}\right.$ at $\left.10 \mathrm{~min}\right)$ and thawing $\left(65^{\circ} \mathrm{C}\right.$ at $\left.10 \mathrm{~min}\right)$. The DNA was purified by phenol-chloroform-isoamyl alcohol (25:24:1), precipitated with sodium acetate and isopropanol, washed with ethanol and eluted with $10 \mathrm{mM}$ Tris buffer. The sample was subjected to three cycles of freezing $\left(-70{ }^{\circ} \mathrm{C}\right.$ for $\left.10 \mathrm{~min}\right)$ and thawing $\left(10 \mathrm{~min}\right.$ at $\left.65^{\circ} \mathrm{C}\right)$, and DNA extracted from the lysate by phenol-chloroform extraction and ethanol precipitation. 
The gene 16S rRNA was amplified by polymerase chain reaction (PCR) using $27 \mathrm{~F}$ (5'AGA GTT TGA TCM TGG CTC AG3' ${ }^{23}$ and $1492 \mathrm{R}\left(5^{\prime} \mathrm{CGG}\right.$ TTA CCT TGT TAC GAC TT3'). ${ }^{24}$ The PCR amplification was performed in a final volume of $25 \mu \mathrm{L}$ total containing $5 \mu \mathrm{L}$ of $5 \mathrm{X}$ Green Gotaq (Promega), $0.5 \mu \mathrm{L}$ of dNTPs $(10 \mathrm{mM}), 1.0 \mu \mathrm{L}$ of each primer $(10 \mu \mathrm{M}), 0.125 \mu \mathrm{L} \mathrm{Taq}$ polymerase $\left(5 \mathrm{U}_{\mu} \mathrm{L}^{-1}\right.$, GoTaq, Promega), 1.0 $\mu \mathrm{L}$ of template DNA, and water to complete. The PCR cycling was performed under the following conditions: $95{ }^{\circ} \mathrm{C}$ for $3 \mathrm{~min}$, followed by 30 cycles of $95{ }^{\circ} \mathrm{C}$ for $30 \mathrm{~s}, 54.8^{\circ} \mathrm{C}$ for $30 \mathrm{~s}$, and $72{ }^{\circ} \mathrm{C}$ for $1 \mathrm{~min}$, with a final extension at $72{ }^{\circ} \mathrm{C}$ for $5 \mathrm{~min}$. The PCR product was analyzed by electrophoresis on a $1 \%$ agarose gel stained with $\mathrm{SYBR}^{\mathrm{TM}}$ Safe DNA gel stain (Invitrogen) and cleaned with ExoSAP-IT (Affymetrix). The sequencing was conducted at the Laboratório de Genética Molecular Humana (LGMH), Departamento de Genética of Universidade Federal de Pernambuco (UFPE) using Bigdye ${ }^{\mathrm{TM}}$ terminator v3.1 cycle sequencing kit (ThermoFisher). Sequences were obtained in both forward and reverse directions. Chromatograms were checked and the sequences edited using Geneious R10 software..$^{25}$ The sequence obtained in this study was compared with the $\mathrm{NCBI}^{16}$ database using the basic local alignment search tool (BLAST) and deposited under the accession number MK163342. For the construction of the phylogenetic tree, some sequences were downloaded from $\mathrm{NCBI}^{16}$ and the aligned was performed using MAFFT v7.222. ${ }^{26}$ The phylogenetic tree was constructed with Geneious R10 software ${ }^{25}$ using inference by the neighbor-joining (NJ) ${ }^{27}$ method with bootstrap based on 1000 replication and by Tamura-Nei genetic distance model. The tree obtained was visualized using FigTree v1.4.2. ${ }^{28}$

\section{Isolation and purification of chromomycins}

Streptomyces sp. (BRA-384) was grown in A1 broth (100 g soluble starch, $40 \mathrm{~g}$ yeast extract and $20 \mathrm{~g}$ peptone) supplemented with $1 \mathrm{~g}$ calcium carbonate, $5 \mathrm{~g} \mathrm{Fe}_{2}\left(\mathrm{SO}_{4}\right)_{3}$ and $5 \mathrm{~g} \mathrm{KBr}$, dissolved in $1 \mathrm{~L}$ of artificial seawater. The culture broth $(8 \mathrm{~L})$ was fermented during 6 days under $150 \mathrm{rpm}$ agitation at $28{ }^{\circ} \mathrm{C}$ and extracted with EtOAc. The solvent was removed under reduced pressure to yield $230 \mathrm{mg}$ of a crude extract that was purified by semi-preparative HPLC using a $\mathrm{C}_{18}$ column, and a gradient solvent system: solvent A $\left[\mathrm{H}_{2} \mathrm{O}\left(\mathrm{CF}_{3} \mathrm{CO}_{2} \mathrm{H}\right.\right.$ acid $\left.\left.0.01 \%\right)\right]$ and solvent $\mathrm{B}[\mathrm{MeCN}$ $\left(\mathrm{CF}_{3} \mathrm{CO}_{2} \mathrm{H}\right.$ acid $\left.0.01 \%\right)$ ], ranging from $50-100 \% \mathrm{~B}$ in $15 \mathrm{~min}$, monitored in the 280 and $410 \mathrm{~nm}$ channels, with rate flow of $4.72 \mathrm{~mL} \mathrm{~min}^{-1}$, to obtain compounds: 1 (10.0 $\mathrm{mg}$, retention time $\left.\left(t_{R}\right) 7.45 \mathrm{~min}\right), 2\left(4.8 \mathrm{mg}, \mathrm{t}_{\mathrm{R}} 8.80 \mathrm{~min}\right), \mathbf{3}(5.7 \mathrm{mg}$, $\left.\mathrm{t}_{\mathrm{R}} 10.18 \mathrm{~min}\right)$ and $4\left(1.1 \mathrm{mg}, \mathrm{t}_{\mathrm{R}} 11.58 \mathrm{~min}\right)$.

\section{Chromomycin $\mathrm{A}_{6}$ (1)}

Yellow amorphous powder; $[\alpha]_{\mathrm{D}}^{20}+48.2^{\circ}(c 0.1, \mathrm{MeOH})$; $\mathrm{UV}(\mathrm{MeOH}) \lambda / \mathrm{nm} \mathrm{411,320,} 278$ and 230; ${ }^{1} \mathrm{H}$ NMR $\left(500 \mathrm{MHz}, \mathrm{CDCl}_{3}\right)$ and ${ }^{13} \mathrm{C} \mathrm{NMR}\left(75 \mathrm{MHz}, \mathrm{CDCl}_{3}\right.$ ) see Table 1; HRESIMS (negative mode) $\mathrm{m} / \mathrm{z}$, calcd. for $\mathrm{C}_{57} \mathrm{H}_{82} \mathrm{O}_{26}[\mathrm{M}-\mathrm{H}]^{-}:$: 181.5022 , found: 1181.4999 .

\section{Chromomycin $\mathrm{A}_{7}$ (2)}

Yellow amorphous powder; $[\alpha]_{\mathrm{D}}^{20}+18.4^{\circ}(c 0.1, \mathrm{MeOH})$; $\mathrm{UV}(\mathrm{MeOH}) \lambda / \mathrm{nm} \mathrm{412,} \mathrm{320,} 280$ and 229; ${ }^{1} \mathrm{H}$ NMR $\left(500 \mathrm{MHz}, \mathrm{CDCl}_{3}\right)$ and ${ }^{13} \mathrm{C} \mathrm{NMR}\left(75 \mathrm{MHz}, \mathrm{CDCl}_{3}\right)$ see Table 1; HRESIMS (negative mode) $\mathrm{m} / \mathrm{z}$, calcd. for $\mathrm{C}_{58} \mathrm{H}_{84} \mathrm{O}_{26}[\mathrm{M}-\mathrm{H}]^{-}:$: 1195.5178, found: 1195.5169 .

\section{Chromomycin $\mathrm{A}_{8}$ (4)}

Yellow amorphous powder; $[\alpha]_{\mathrm{D}}^{20}+8.1^{\circ}(c 0.1, \mathrm{MeOH})$; $\mathrm{UV}(\mathrm{MeOH}) \lambda / \mathrm{nm} \mathrm{411,320,} 278$ and 230; ${ }^{1} \mathrm{H}$ NMR (500 MHz, $\mathrm{CDCl}_{3}$ ) see Table 1; HRESIMS (negative mode) $m / z$, calcd. for $\mathrm{C}_{60} \mathrm{H}_{88} \mathrm{O}_{26}[\mathrm{M}-\mathrm{H}]^{-}:$1223.5491, found: 1223.5455 .

Investigation of the time influence on the extract yielding, biomass production and chromomycins bioproduction

Triplicates of BRA-384 strain were inoculated in Erlenmeyer flasks containing $250.0 \mathrm{~mL}$ of medium A1, kept under constant stirring at $170 \mathrm{rpm}$. The extractions were performed in the time intervals: $1 \mathrm{~h}$ (0.04 day) followed by $1,3,5,7$ and 9 days, with $200.0 \mathrm{~mL}$ of EtOAc under stirring at $130 \mathrm{rpm}$ for $2 \mathrm{~h}$. Some BRA-384 broths were filtered at day 1 using a $0.22 \mu \mathrm{m}$ vacuum filtration system (Sarsted). These extractions of the bacteria-free broths were performed on the days 3, 5, 7 and 9. To determine the biomass dry weight, after the extraction process, the biomass-containing the growth medium was filtered on filter paper (Whatman) using a vacuum system and then dried in an oven at $80{ }^{\circ} \mathrm{C}$ for $40 \mathrm{~min}$. The weight of the extracts and biomass were measured.

\section{Cell lines, cell culture maintenance and cytotoxic assay}

The 501-mel (human metastatic melanoma), MM200 (human melanoma) and HCT 116 (human colon adenocarcinoma) cells were grown in Roswell Park Memorial Institute medium (RPMI), while MCF-7 (human breast carcinoma), PC-3M (human metastatic prostate cancer), were grown in Dulbecco's modified eagle medium (DMEM), both media were supplemented with $10 \%$ fetal bovine serum (FBS), $1 \%$ penicillin $\left(10,000 \mathrm{IU} \mathrm{mL}^{-1}\right)$ and streptomycin $\left(10,000 \mu \mathrm{g} \mathrm{mL}^{-1}\right)$ antibiotics. Cells were kept in an incubator with $5 \% \mathrm{CO}_{2}$ at $37{ }^{\circ} \mathrm{C}$ and regularly split 
to maintain them into exponential growth state. HCT 116 was used for the initial screening of the active extracts and for the bioguided fractionation of BRA-384 extract as well.

The antiproliferative activity was evaluated by the MTT (3-(4,5-dimethylthiazol-2-yl)-2,5-diphenyltetrazolium bromide) assay. ${ }^{29}$ The cells were seeded on 96-well plates at a density of $1 \times 10^{4}$ (501-mel, MM200, HCT 116 and MCF-7) or $3 \times 10^{4}(\mathrm{PC}-3 \mathrm{M})$ per well with $200 \mu \mathrm{L}$ culture medium. After $24 \mathrm{~h}$, extracts and fractions ( 0.00064 to $\left.50 \mu \mathrm{g} \mathrm{mL}^{-1}\right)$ or compounds 1-4 (0.016 to $1000 \mathrm{nM})$ were added to the cultures and incubated during $69 \mathrm{~h}$. Dimethyl sulfoxide (DMSO, 0.05\%) was used as negative control and the antineoplastic compound doxorubicin (0.64 to $10,000 \mathrm{nM})$ was used as positive control. After treatment, culture media were replaced by fresh media containing MTT solution $\left(0.5 \mathrm{mg} \mathrm{mL}^{-1}\right)$ and incubated for additionally $3 \mathrm{~h}$. The MTT solution was, then, removed and the plates dried at $35{ }^{\circ} \mathrm{C}$ for $30 \mathrm{~min}$. The formazan product was solubilized in $150 \mu \mathrm{L}$ of DMSO and the absorbance was read at $570 \mathrm{~nm}$. The inhibition concentration means $\left(\mathrm{IC}_{50}\right)$ values and their $95 \%$ confidence intervals (CI 95\%) were calculated by nonlinear regression of the normalized absorbance data to percentage of growth inhibition using GraphPad Prism 6.1 software. ${ }^{30}$

\section{Supplementary Information}

Supplementary information (experimental, NMR comparison of chromomycin, NMR spectra and HRESIMS of isolated compounds) is available free of charge at http://jbcs.sbq.org.br as PDF file.

\section{Acknowledgments}

The authors gratefully acknowledge financial support and fellowships from the National Council for Scientific and Technological Development (CNPq, Conselho Nacional de Desenvolvimento Científico e Tecnológico), grants Nos. 420454/2016-0 and 309060/2016-8, National Institute of Science and Technology (INCTBioNat), grant No. 465637/2014-0 and FAPESP (2015/17177-6, 2017/17648-4 and 2014/50926-0).

\section{References}

1. Aftab, U.; Zechel, D. L.; Sajid, I.; Biol. Res. 2015, 48, DOI: 10.1186/s40659-015-0046-3.

2. Ramesh, S.; Aalbersberg, W.; Microbiol. Res. 2012, 167, 571.

3. Lu, Y.; Xing, Y.; Chen, C.; Lu, J.; Ma, Y.; Xi, T.; Phytochem. Lett. 2012, 5, 459.

4. Hu, Y.; Espindola, A. P. D. M.; Stewart, N. A.; Wei, S.; Posner, B. A.; MacMillan, J. B.; Bioorg. Med. Chem. 2011, 19, 5183.
5. Newman, D. J.; Cragg, G. M.; J. Nat. Prod. 2016, 79, 629.

6. Menéndez, N.; Nur-e-Alam, M.; Fischer, C.; Braña, A. F.; Salas, J.A.; Rohr,J.; Méndez, C.;Appl. Environ. Microbiol. 2006, 72, 167.

7. Menéndez, N.; Nur-e-Alam, M.; Braña, A. F.; Rohr, J.; Salas, J. A.; Méndez, C.; Mol. Microbiol. 2004, 53, 903; García, B.; González-Sabín, J.; Menéndez, N.; Braña, A. F.; Núñez, L. E.; Morís, F.; Salas, J. A.; Méndez, C.; Microb. Biotechnol. 2011, 4, 226.

8. Menéndez, N.; Nur-e-Alam, M.; Braña, A. F.; Rohr, J.; Salas, J. A.; Méndez, C.; Chem. Biol. 2004, 11, 21.

9. Lombó, F.; Menéndez, N.; Salas, J. A.; Méndez, C.; Appl. Microbiol. Biotechnol. 2006, 73, 1.

10. Pettit, G. R.; Tan, R.; Pettit, R. K.; Doubek, D. L.; Chapuis, J.-C.; Weber, C. A.; RSC Adv. 2015, 5, 9116.

11. Sun, L.; Zeng, J.; Cui, P.; Wang, W.; Yu, D.; Zhan, J.; J. Biol. Eng. 2018, 12, DOI: 10.1186/s13036-018-0103-x.

12. Boer, D. R.; Canals, A.; Coll, M.; Dalton Trans. 2009, 399.

13. Zihlif, M.; Catchpoole, D. R.; Stewart, B. W.; Wakelin, L. P. G.; Cancer Genomics Proteomics 2010, 7, 323.

14. Guimarães, L. A.; Jimenez, P. C.; Sousa, T. S.; Freitas, H. P. S.; Rocha, D. D.; Wilke, D. V.; Martín, J.; Reyes, F.; Pessoa, O. D. L.; Costa-Lotufo, L. V.; Mar. Drugs 2014, 12, 5839.

15. Pinto, F. C. L.; Almeida, J. G. L.; Silveira, E. R.; Costa, A. M.; Guimarães, L. A.; Wilke, D. V.; Costa-Lotufo, L. V.; Torres, M. C. M.; Pessoa, O. D. L.; J. Braz. Chem. Soc. 2017, 28, 485; Almeida, J. G. L.; Maia, A. I. V.; Wilke, D. V.; Silveira, E. R.; Braz-Filho, R.; La Clair, J. J.; Costa-Lotufo, L. V.; Pessoa, O. D. L.; Mar. Drugs 2012, 10, 2846; Wilke, D. V.; Jimenez, P. C.; Pessoa, C.; de Moraes, M. O.; Araujo, R. M.; da Silva, W. M. B.; Silveira, E. R.; Pessoa, O. D. L.; Braz-Filho, R.; Lopes, N. P.; Costa-Lotufo, L. V.; J. Braz. Chem. Soc. 2009, 20, 1455; Costa-Lotufo, L. V.; Carnevale-Neto, F.; Trindade-Silva, A. E.; Silva, R. R.; Silva, G. G. Z.; Wilke, D. V.; Pinto, F. C. L.; Sahm, B. D.; Jimenez, P. C.; Mendonça, J. N.; Lotufo, T. M. C.; Pessoa, O. D. L.; Lopes, N. P.; Chem. Commun. 2018, 54, 1952.

16. http://www.ncbi.nlm.nih.gov/, accessed in June 2019.

17. Miyamoto, M.; Kawamatsu, Y.; Kawashima, K.; Shinohara, M.; Tanaka, K.; Tatsuoka, S.; Nakanishi, K.; Tetrahedron 1967, 23 , 421.

18. Toume, K.; Tsukahara, K.; Ito, H.; Arai, M. A.; Ishibashi, M.; Mar. Drugs 2014, 12, 3466.

19. Norio, S.; Eiji, H.; Takashi, S.; Mitsuko, A.; Kimiaki, M.; Jpn. pat. 521022021977.

20. Oki, T.; Matsuzawa, Y.; Numata, K.; Takamatsu, A.; J. Antibiot. 1973, 11, 701.

21. Kawano, T.; Hidaka, T.; Furihata, K.; Mochizuki, J.; Nakayama, H.; Hayakawa, Y.; Seto, H.; J. Antibiot. 1990, 43, 110.

22. Garcia, G. D.; Gregoracci, G. B.; Santos, E. O.; Meirelles, P. M.; Silva, G. G. Z.; Edwards, R.; Sawabe, T.; Gotoh, K.; Nakamura, S.; Iida, T.; Moura, R. L.; Thompson, F. L.; Microb. Ecol. 2013, 65, 1076. 
23. Heuer, H.; Krsek, M.; Baker, P.; Smalla, K.; Wellington, E. M. H.; Appl. Environ. Microbiol. 1997, 63, 3233.

24. Jiang, H.; Dong, H.; Zhang, G.; Yu, B.; Chapman, L. R.; Fields, M. W.; Appl. Environ. Microbiol. 2006, 72, 3832.

25. https://www.geneious.com, accessed in June 2019.

26. Katoh, K.; Misawa, K.; Kuma, K.; Miyata, T.; Nucleic Acids Res. 2002, 30, 3059.

27. Saitou, N.; Nei, M.; Mol. Biol. Evol. 1987, 4, 406.
28. Rambaut, A.; FigTree, version 1.4.2.; University of Edinburgh, UK, 2014. Available at http://tree.bio.ed.ac.uk/software/figtree/, accessed in June 2019.

29. Mosmann, T.; J. Immunol. Methods 1983, 65, 55.

30. GraphPad Prism 6.1; Intuitive Software for Science, San Diego, CA, 2015.

Submitted: February 13, 2019

Published online: June 25, 2019 